DOI 10.37882/2500-3682.2021.05.04

\title{
NATURAL HORSEMANSHIP: TEOPETИЧЕСКИЕ АСПЕКТЫ ИЗУЧЕНИЯ КОММУНИКАЦИИ МЕЖДУ ЧЕЛОВЕКОМ И ЛОШАДЬЮ
}

\section{NATURAL HORSEMANSHIP: THEORETICAL ASPECTS OF STUDYING HUMAN-HORSE COMMUNICATION}

\author{
O. Bagno \\ S. Rassolov \\ A. Libontova \\ N. Ravochkin
}

Summary: In this work, the authors attempt to analyze the natural skill of one of the most promising communication systems between man and horse. The theoretical and methodological foundations were provided by modern scientific domestic and foreign works, as well as analytical and comparative methods. The significance of the study of interspecies interaction in modern psychology is presented. Shows the evolution of the relationship between man and horse in a historical retrospective. The Natural Horsemanship System is comprehensively reviewed. Comparative studies between $\mathrm{NH}$ and traditional training systems are presented. In conclusion, the authors summarize the work and provide positive effects in their applied aspect.

Keywords: communication, interspecies interaction, man, horse, psychophysiology, training, care.
Багно Ольга Александровна

Кузбасская государственная сельскохозяйственная академия

Рассолов Сергей Николаевич

Кузбасская государственная сельскохозяйственная академия

Либонтова Арина Игоревна

Кузбасская государственная сельскохозяйственная академия

Равочкин Никита Николаевич

Кузбасская государственная сельскохозяйственная академия; Кузбасский государственный технический университет имени Т.Ф. Горбачева nickravochkin@mail.ru

Аннотация: В настоящей работе авторы предпринимают попытку анализа Natural Horsemanship одной из перспективных систем коммуникативного взаимодействия между человеком и лошадью. Теоретико-методологическими основаниями послужили современные научные отечественные и зарубежные работы, а также аналитический и компаративистский методы. Представлена значимость исследования межвидового взаимодействия в современной психологии. Показана эволюция отношений между человеком и лошадью в исторической ретроспективе. Всесторонне рассмотрена система Natural Horsemanship. Приводится компаративистика между NH и традиционными системами тренинга. В заключение авторы подводят итоги работы и приводят перечень позитивных эффектов в их прикладном аспекте.

Ключевые слова: коммуникация, межвидовое взаимодействие, человек, лошадь, психофизиология, тренинг, забота.

В данной работе мы сосредоточимся на раскрытии теоретических аспектов коммуникации человека с лошадью. Пожалуй, следует начать с того, что роль животных на протяжении эволюции человека, ставшего таковым и не имевшим при этом морфологических адаптаций хищника, в самых различных исторических условиях получает достаточно высокие оценки. На наш взгляд, всю шкалу оценок роли домашних и сельскохозяйственных наиболее удачно было бы отобразить в виде бинарной оппозиции «преклонение - радикальный прагматизм». Без всякого преувеличения отметим, что те или иные животные практически всегда олицетворяют собой какието новые возможности для Homo Sapiens. К примеру, хитрость кошачьих или способности к полету мифического Пегаса - вот лишь немногочисленные примеры поистине партнерских отношений между человеком и животными.

Так почему же актуально изучать взаимодействия 
человека и лошади? Помимо полушуточного аргумента, взятого нами из творчества Киплинга, отражающего значимость лошади в цивилизации (напомним, что именно она второй после собаки пришла на службу человеку), укажем и на то, что эти животные являются социальными. По этому поводу Т.В. Доронина пишет, что «их выживание зависит от умения вести совместную жизнедеятельность внутри табуна, в котором существует своя иерархия, сохраняющаяся на протяжении длительного времени» [2, С. 220].

Наконец, даже неглубинная аналитика исторического материала даст подтверждения многочисленным фактам непрерывного взаимодействия человека с лошадьми, а по состоянию и уровню развитию коневодства вообще судили о способности государств сохранять свою независимость. Американские профессора Кьисон и Абрамсон дают достаточно подробное ретроспективное резюме: «Лошади были одомашнены тысячи лет назад для транспорта, сельского хозяйства и ведения войны. Их роль в истории, в первую очередь, была сосредоточена на обеспечении скорости и силы для отдельных людей и общества. Современность изменила их роль, и теперь лошадей рассматривают в качестве друзей, используют для развлечения и терапии. Однако взаимодействие между человеком и лошадью не изменилось, и нам необходимо заново оценить взаимодействие с лошадьми, чтобы наилучшим образом определить новую роль этих уникальных существ в обществе» [3, С. 342].

Постиндустриальный мир отошел от прежней сверхэксплуатации лошади (охота, прогулки, получение мяса и молока, турниры) со стороны человека, тем самым хабитуализировав множество отражающих заботу, любовь и привязанность практик взаимодействия. Одной из наиболее интересных среди таковых нам представляется «Natural Horsemanship» (HX), которая появилась в 80-е гг. прошлого столетия в США. Любопытно, что принципы успешного обучения лошадей «без сопротивления» восходят еще к античной мысли и описаны в трудах Гомера, Ксенофонта, Аристотеля и других. Свою реализацию они получили конниками, оттачивавшими просовременные ездовые практики на протяжении столетий. Первоначально данная система оформилась в качестве новых наезднических методик стиля «вестерн», а ее популяризация корреспондировала с уже отмеченной нами во введении популярности психологии межвидового взаимодействия, а также первоначально с вполне утилитарными целями обучения лошадей. В последующем система HX также перенеслась и на другие виды езды. Не уходя в детальный разбор, мы оцениваем достигнутые с того времени высокие результаты исключительно в позитивной модальности. Неудивительно, что перспективная система Natural Horsemanship относительно стремительно покинула границы США, найдя свое практическое применение в других странах. К слову, в России ее интерпретируют достаточно широко как «натуральные или естественные отношения» [5;7].

Говоря в целом, лошади являются достаточно сложными в содержании и одновременно с этим высокочувствительными животными. Однако ключевой момент обучения NH фундирован своевременным снятием давления. В частности, согласно рассматриваемой системе, создание дискомфорта посредством команды подразумевает необходимость его незамедлительного снятия. Таким образом, в условиях комфорта лошадь даст правильную реакцию («ответ») на команду. Еще HX обращается к технологии так называемого «отрицательного подкрепления» (похвала за правильные действия), что выступает своего рода поощрением для лошадей, которые используют эти же принципы и в общении друг с другом. И.А. Дитман показывает, что «обмен информацией происходит между лошадьми, однако когда с лошадью начинает общаться человек, она продолжает подавать привычные сигналы и чутко следить за реакцией партнера, следовательно, появляется возможность использования языка тела для качественного улучшения коммуникации. Подходя к лошади впервые, знакомясь с ней или приветствуя, как старого знакомого, мы выражаем наши чувства и эмоции через мимику лица, движения корпуса, жесты рук» [1, С. 57].

Тренер П. Парелли называл Natural Horsemanship «обучением в игре» [6]. Скорее всего, он связывал это с тем, что лошади уделяют большое количество внимание форме предметов, отмечал, что прежде всего люди должны стараться разнообразить обстановку, тем самым им будет проще найти варианты позитивного доведения до лошади необходимой команды. Выходит, инновационность HX можно связать с тем, что данная технология первоначально делает упор на коммуникативной стороне посредством установления контакта между человеком и лошадью, и только уже затем направлено на развитие движений. Это во многом отличается от абсолютного большинства традиционных тренинговых систем, в рамках которых лошади сразу же подпадают под обучение «специализации», тогда как психологический аспект может быть попросту проигнорирован. На наш взгляд, HX позволяет лошади не только привыкнуть к биомеханическим особенностям человека, относительным движениям отдельных частей тела и позам, но и понимать людские чувства, эмоции и, конечно же, оценивать их уверенность в себе. Также Natural Horsemanship способствует тому, что лошадь формирует для себя «истинное состояние индивида». Реагируя на субъективный образ в определенном ключе, лошадь начинает выстраивать отношения с оказавшемся в ее пространстве человеком. Таким образом, обобщение и систематизация знаний в HX открыли широкий спектр возможностей не только для теоретико-методологической базы межвидового взаимодействия, но и главным образом в прикладном 
Таблица 1.

Основные принципы традиционной системы тренинга лошадей и Natural Horsemanship

\begin{tabular}{|c|c|c|}
\hline \multirow{2}{*}{ Показатель } & \multicolumn{2}{|c|}{ Система тренинга лошадей } \\
\hline & традиционная & NaturalHorsemanship \\
\hline Использование приемов обучения & Характерные для определенного вида спорта & $\begin{array}{c}\text { Формирует мышление, с помощью которого } \\
\text { можно формировать любую программу обучения } \\
\text { лошади }\end{array}$ \\
\hline Основа общения человека с лошадью & Принуждение & Лидерство \\
\hline Обучение лошади быть безопасной для человека & Отсутствует & Присутствует \\
\hline Основа для обучения лошади & $\begin{array}{l}\text { Создание дискомфорта для лошади, механиче- } \\
\text { ское удержание средствамиуправления или страх }\end{array}$ & $\begin{array}{c}\text { Своевременное снятие давления, стремление } \\
\text { лошади от дискомфорта к комфорту, желание } \\
\text { лошади сотрудничать и ее моральная готовность } \\
\text { выполнить команду }\end{array}$ \\
\hline $\begin{array}{c}\text { Наличие специального образования для 06- } \\
\text { учения лошади }\end{array}$ & Не обязательно & 0бязательно \\
\hline $\begin{array}{c}\text { Принадлежность лошади к определенной по- } \\
\text { роде, полу, возрасту и т.д. }\end{array}$ & Учитывается & Не учитывается \\
\hline Основной принцип обучения лошади & Зависит от направления использования лошади & Обучение в игре \\
\hline $\begin{array}{c}\text { Основное место нахождения человека во время } \\
\text { обучения лошади }\end{array}$ & На лошади & Рядом с лошадью \\
\hline Выделение отдельного времени под обучение & Требуется & $\begin{array}{l}\text { Не требуется, обучение проводится при чистке, } \\
\text { кормлении, езде и т.д. }\end{array}$ \\
\hline $\begin{array}{c}\text { Реакция человека на неправильное поведение } \\
\text { лошади }\end{array}$ & Наказание & $\begin{array}{c}\text { Недопущение или коррекция на ранних этапах } \\
\text { обучения }\end{array}$ \\
\hline $\begin{array}{c}\text { Реакция человека на правильное поведение } \\
\text { лошади }\end{array}$ & Поощрение & Поощрение в виде лакомства не обязательно \\
\hline Использование снаряжения & $\begin{array}{c}\text { 0бязательно, используется как средство механи- } \\
\text { ческого удержания и подчинения }\end{array}$ & $\begin{array}{c}\text { Допускается, используется как средство подачи } \\
\text { команд }\end{array}$ \\
\hline
\end{tabular}

аспекте позволили сконструировать качественно иной образ мышления и способ(ы) общения между людьми и лошадьми $[1 ; 5 ; 6 ; 7]$. Компаративистика между NH и традиционной системой тренинга представлена ниже в таблице 1.

Продолжая рассуждения, отметим, что потенциал $\mathrm{HX}$ выходит только лишь за границы успешного развития индивидуальных навыков владения лошадью и умений держаться в седле. По мнению авторов, рассмотренная система межвидового взаимодействия становится мощным инструментом оздоровления человека и формиро- вания у него дополнительных навыков просоциального поведения. Одновременно с этим коммуникативная успешность удовлетворяет актуальную человеческую потребность в субъектификации лошади, что позволяет людям приобрести дополнительную лояльность в глазах животного. В заключение статьи, помимо высвечивания нами терапевтического потенциала анималотерапии (в данном случае речь идет об иппотерапии) для физиологии человека, отмечаем, что взаимодействия с лошадью открывают к человеку путь к самому себе и глубинным слоям психики, а также способствуют повышению уровня осознанности совершаемых действий.

\section{ЛИТЕРАТУРА}

1. Дитман И.А. Язык тела в коммуникациях с лошадьми // Иппология и ветеринария. 2011. № 2 (2). С. 56-58.

2. Доронина Т.В. Взаимосвязь эмоционального состояния человека и эффективности его работы с лошадью в процессе иппотерапии // В сборнике: Сборник избранных статей по материалам научных конференций ГниИ «Нацразвитие». Материалы Конференций Гнии «Нацразвитие». Выпускающий редактор Ю.Ф. Эльзессер; Ответственный за выпуск С.В. Викторенкова. 2019. С. 219-221.

3. Кьисон Э., Абрамсон Ч.И. Коммуникация лошади и человека: обзор истории и перспективы // В сборнике: Психология в современном мире. сборник статей Международной научно-практической конференции. Под ред. О.В. Кащеева, И.В. Антоненко, И.Н. Карицкого. 2017. С. 342-344. 
4. Шукова Г.В. Психологические аспекты межвидового взаимодействия человека и домашних животных // Вестник Российского гуманитарного научного фонда. 2016. № 2 (83). С. 155-166.

5. Anderson C. Downunder Horsemanship. Trafalgar Square Books, 2004. $206 \mathrm{p}$.

6. Parelli P. Natural Horsemanship. Western Horseman magazine, 2003. $223 \mathrm{p}$.

7. Rashid M. Horsemanship through life. Johnson Books, 2005. 198 p.

( ) Багно Ольга Александровна, Рассолов Сергей Николаевич, Либонтова Арина Игоревна,

Равочкин Никита Николаевич (nickravochkin@mail.ru).

Журнал «Современная наука: актуальные проблемы теории и практики»

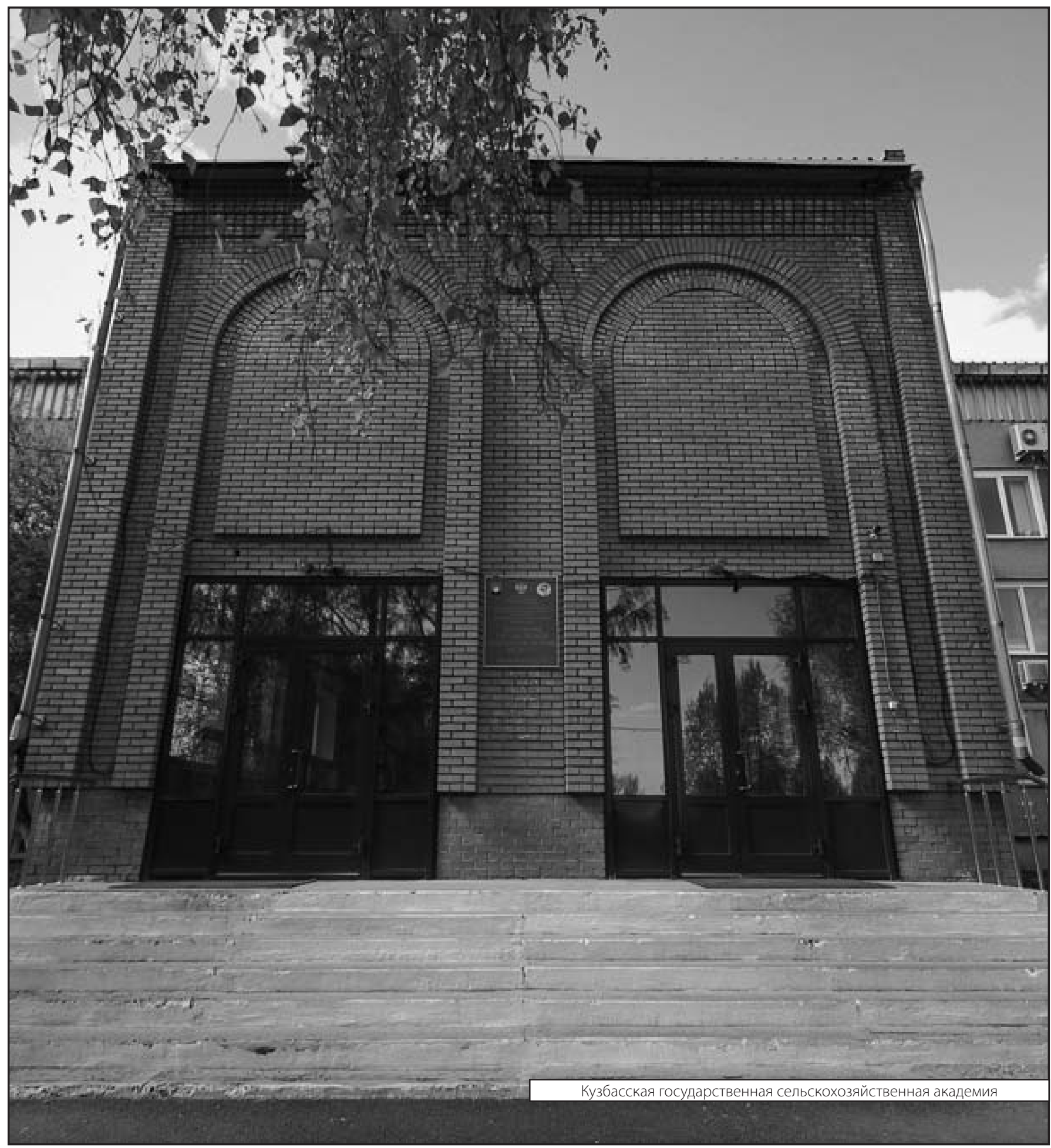

